\title{
THIRD SPECIES OF MONOPHYLLORCHIS (ORCHIDACEAE) DISCOVERED IN PANAMA
}

\author{
MARTA KolanOwSKA
}

\begin{abstract}
A new species of Monophyllorchis Schltr. is described and illustrated based on Panamanian material. In habit the species resembles M. maculata Garay and its flowers are similar to M. microstyloides (Rchb. f.) Garay. The new entity is placed within an identification key for Monophyllorchis species.
\end{abstract}

Key words: Monophyllorchis, Neotropics, new species, orchids, Panama, taxonomy

Marta Kolanowska, Department of Plant Taxonomy and Nature Conservation, University of Gdańsk, Wita Stwosza 59, 80-308 Gdańsk, Poland; e-mail: martakolanowska@wp.pl

\section{INTRODUCTION}

The Neotropical genus Monophyllorchis Schltr. was described by Schlechter (1920) based on a single Colombian collection which was deposited in the Berlin-Dahlem Herbarium and was destroyed during World War II. Only a drawing of the type material of $M$. colombiana Schltr., deposited in the Orchid Herbarium of Oakes Ames, remains. More than 40 years after Schlechter's description of the genus, Garay (1962) found another species which he identified as a representative of Monophyllorchis: Pogonia microstyloides Rchb. f. described in 1886 by Reichenbach. Since the type of P. microstyloides (Rchb. f.) Garay is almost identical with the drawing made by Schlechter, those two species were synonymized under the name Monophyllorchis microstyloides (Garay 1978). In 1978 the second species of the genus, M. maculata Garay was described by Garay (1978) based on Ecuadorian material. The two species differ in both vegetative and floral characters, but Dressler (2003) proposed treating the latter as a synonym of M. microstyloides. The specific composition of the genus is problematic due to insufficient herbarium material, which is often poorly preserved or completely lacks flowers.

The unsatisfactory collections of Monophyllorchis and its allied genera, Psilochilus Barb.
Rodr., Pogonia Juss. and Triphora Nutt., have also caused problems with classification of the genus. Schlechter (1926) considered all three genera to be representatives of Vanilleae (Monandreae, Acrotonae, Polychondreae). Dressler (1979) included Psilochilus, Triphora and Monophyllorchis in the newly created tribe Triphoreae, but Szlachetko (1995) found the gynostemium characters of the latter genus to be distinct and separated it in the monotypic subtribe Monophyllorchidinae. While Szlachetko followed Schlechter's classification placing Triphoreae among the vanilloid orchids, Dressler considered it an epidendroid taxon. Chase et al. (2003) also included in the tribe Diceratostele, recognized previously as a member of the separated tribe Diceratosteleae.

Despite the classification chaos, the distinctiveness of Monophyllorchis is widely accepted. Its representatives produce slender, terete stems with a single apical leaf. The small, thin, glabrous flowers are arranged in a terminal, elongate inflorescence. All the tepals are free and the 3-lobed lip slightly enfolds the gynostemium. The gynostemium is elongate, erect, and slightly swollen in the upper part, with the column part much longer than the anther. The anther is incumbent, ellipsoidovoid to ovoid-conical, and motile. Four powdery, 
soft and mealy pollinia are produced. The ventral stigma is 3-lobed and elliptic to transversely elliptic (Szlachetko \& Rutkowski 2000).

Plants of Monophyllorchis grow terrestrially in wet forests and their occurrence has been reported from 400-1700 $\mathrm{m}$ a.s.l. The geographical range of the genus extends from Nicaragua to Ecuador.

As mentioned before, usually two species of Monophyllorchis are recognized. One of them, M. maculata, was reported from Panama (Correa et al. 2004), but since M. microstyloides was found in neighboring Costa Rica and Colombia its occurrence in Panama cannot be excluded. During my revision of herbarium material deposited in the herbarium of the University of Panama (PMA) I found a distinct species of Monophyllorchis, and describe it here.

\section{DESCRIPTION OF THE NEW SPECIES}

Monophyllorchis isthmica Kolan., sp. nov.

Figs $1 \& 2$

Species similar to M. microstyloides (Rchb. f.) Garay but with a wide ovate leaf, conspicuous isthmus between the lip lobes, ovate lip lateral lobes, and transversely elliptic lip middle lobe.

Holotype: PANAMA. Prov. Colón. Santa Rita lumber road, $c a 15 \mathrm{~km}$ east of Colón, $9^{\circ} 20^{\prime} \mathrm{N}, 79^{\circ} 48^{\prime} \mathrm{W}$, 9 Mar. 1968. Dressler 3409 (PMA; IsOTYPE: PMA).

Roots villose. Stem up to $c a 11 \mathrm{~cm}$ long, with large funnel-shaped sheath. Leaf sessile, plicate, blade up to $11 \mathrm{~cm}$ long, $8.8 \mathrm{~cm}$ wide, ovate, acuminate, acute, dark green, with silver streaks on upper ridges. Peduncle $c a 4 \mathrm{~cm}$ long, rachis up to $6.5 \mathrm{~cm}$ long. Flowers tubular, thin, tepals 3-veined. Pedicel and ovary $\mathrm{ca} 13 \mathrm{~mm}$ long. Floral bracts up to $8 \mathrm{~mm}$ long. Dorsal sepal $13.2 \mathrm{~mm}$ long, $2 \mathrm{~mm}$ wide, linear-ligulate, obtuse, somewhat narrower towards base. Petals $12 \mathrm{~mm}$ long, $2.8 \mathrm{~mm}$ wide, obliquely ligulate-oblanceolate, subacute. Lateral sepals $13 \mathrm{~mm}$ long, $3 \mathrm{~mm}$ wide, obliquely oblanceolate, obtuse. Lip $12 \mathrm{~mm}$ long, $5 \mathrm{~mm}$ wide, 3-lobed, lateral lobes ovate, obtuse, spreading; middle lobe $1.8 \mathrm{~mm}$ long, $2.9 \mathrm{~mm}$ wide, transversely elliptic to suborbicular, acute at apex, isthmus between lobules $5 \mathrm{~mm}$ long, $1.7 \mathrm{~mm}$ wide; disc with three thickened veins running along central part of lip. Gynostemium ca $9 \mathrm{~mm}$ long.

ETYMOLOGY. In reference to the conspicuous isthmus between the lip lobes.

Distribution AND Habitat. So far the species is known exclusively from the Panamanian province of Colón, where it was found below $100 \mathrm{~m}$ a.s.1. This terrestrial plant was found growing in evergreen humid lowland forest. Flowering in March.

Conservation status. According to IUCN red list criteria (Anonymous 2014), this new species should be classified as critically endangered
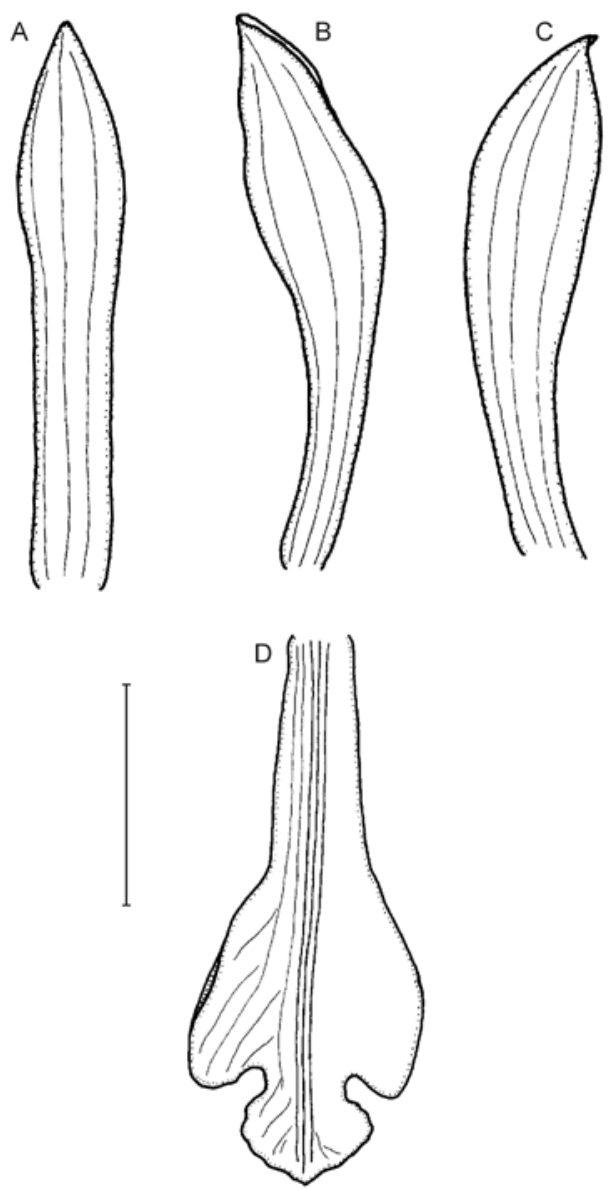

Fig. 1. Monophyllorchis isthmica Kolan., sp. nov. - dissected perianth. (A) Dorsal sepal; (B) lateral sepal; (C) petal; (D) lip. Scale bar $=5 \mathrm{~mm}$. 


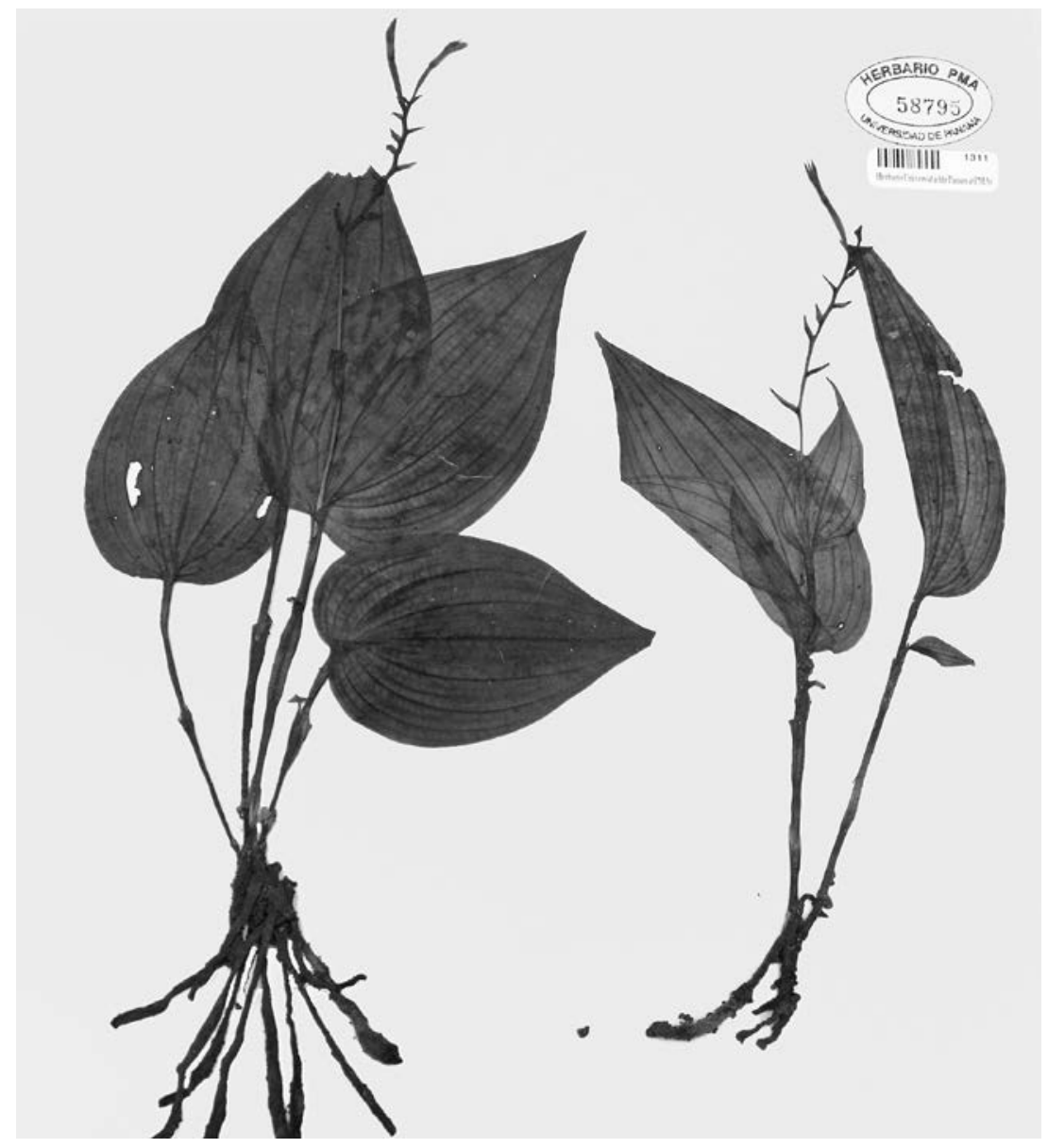

Fig. 2. Monophyllorchis isthmica Kolan., sp. nov. - habit.
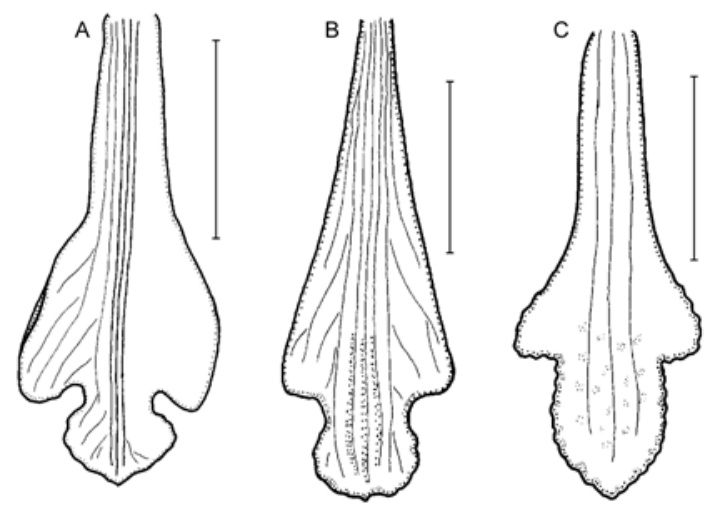

Fig. 3. Lip shape in Monophyllorchis isthmica Kolan., sp. nov. (A), M. microstyloides (Rchb. f.) Garay (B) and M. maculata Garay $(\mathrm{C})$. Scale bars $=5 \mathrm{~mm}$.
[CR B2ab(iii); C2a(i); D1], based on the small number of known populations and its restricted area of distribution.

Notes. While the wide ovate leaf of the new species resembles that observed in M. maculata, in flower morphology it resembles rather $M$. microstyloides. From the latter $M$. isthmica is easily distinguished by its much wider lateral sepals and petals (2.9-3.0 $\mathrm{mm}$ wide vs ca $1.5 \mathrm{~mm}$ wide), its conspicuous isthmus between the lip lobes, ovate lip lateral lobes (vs obliquely triangular) and transversely elliptic lip middle lobe (vs middle lobe semicircular, equally long and wide). Figure 3 compares lip shape between the three Monophyllorhis species. 


\section{KEY TO THE SPECIES OF MONOPHYLLORCHIS}

1. Leaves narrowly ovate-lanceolate to narrowly elliptic ....... M. microstyloides (Rchb. f.) Garay

1. Leaves broadly elliptic-ovate . . . . . . . . . . . 2

2. Lateral lobes exceeding base of middle lobe ... . . . . . . . . . . . . . M. isthmica Kolan.

2. Lateral lobes not exceeding base of middle lobe .................. Maculata Garay

ACKNOwledgements. I thank Professor Dariusz Szlachetko and the anonymous reviewers for valuable comments on the manuscript. The research described here was financed by the Faculty of Biology, University of Gdańsk (538-L150-B065-13).

\section{REFERENCES}

AnONYmous 2014. Guidelines for Using the IUCN Red List Categories and Criteria. Version 11. Prepared by the Standards and Petitions Subcommittee. http://www.iucnredlist. org/documents/RedListGuidelines.pdf

Chase M. W., Cameron K. M., Barrett R. L. \& FreudenSTEIN J. V. 2003. DNA data and Orchidaceae systematics: a new phylogenetic classification. In: K. W. Dixon, S. P. Kell, R. L. Barrett \& P. J. CribB (eds), Orchid conservation, pp. 69-89. Natural History Publications, Kota Kinabalu.
Correa M., Galdames C. \& StapF M. S. 2004. Catálogo de las plantas vasculares de Panamá. Quebecor World, Bogotá.

DrESSLER R. L. 1979. The subfamilies of the Orchidaceae. Selbyana 5: 197-206.

Dressler R. L. 2003. Orchidaceae. In: B. E. Hammel, M. H. Grayum, C. Herrera \& N. Zamora (eds), Manual de plantas de Costa Rica. 3. Monogr. Syst. Bot. Missouri Bot. Gard. 93: 1-595.

Garay L. A. 1962. Studies in American Orchids V. Caldasia 8: 517-529.

Garay L. A. 1978. Orchidaceae, Cypripedioideae, Orchidoideae, Neottioideae. In: G. W. Harling \& B. B. SPARrE (eds), Flora of Ecuador, pp. 1-305. University of Göteborg and Swedish Museum of Natural History, Göteborg and Stockholm.

ReICHENBACH H. 1886. Orchideae describuntur. Flora 69: $547-562$.

SCHLECHTER R. 1920. Orchideenfloren der Suedamerikanischen Kordillerenstaaten, II. Colombia (II. Beschreibungen neuer Arten). Feddes Repert. Beih. 7: 37-161.

Schlechter R. 1926. Das system der Orchidaceae. Notizbl. Bot. Gart. Berlin-Dahlem 9: 563-591.

SzlachetKo D. L. 1995. Systema Orchidalium. Fragm. Florist. Geobot., Suppl. 3: 1-152.

Szlachetko D. L. \& Rutkowski P. 2000. Gynostemia Orchidalium. 1. Apostasiaceae, Cypripediaceae, Orchidaceae (Thelymitroideae to Vanilloideae). Acta Bot. Fenn. 169: $1-415$. 